\title{
Alternative Finance Business-Models: Online Platforms
}

\author{
Pavlo Rubanov \\ $\mathrm{PhD}$, Associate Professor of Finance, Sumy State University, Ukraine
}

\section{Alfredo Marcantonio}

Owner of Insurance Agency, Partner of Continental Insurance Group, Marktoberdorf, Germany

\begin{abstract}
The article explores the essence of alternative finance, describes the main models of alternative financing for business and individual borrowers. The key characteristics of alternative finance models are determined and their classification according to these criteria is proposed. The analysis of the modern development of the basic models of alternative finance in the regions of the world is carried out.
\end{abstract}

Keywords: alternative finance, investments, crowdfunding, peer-to-peer lending, online platform.

JEL Classification: G01, G20, E42.

(C) The Authors, 2017. This article is published with open access at ARMG Publishing.

\section{Introduction}

The alternative financing sector has not been given much attention for a long time, since it was considered that it occupies a small niche in comparison with traditional forms of business lending. However, the crisis in the banking system, the strong development of information technology, the reorientation of innovation from large enterprises to startups have become the factors that have provided a sharp leap in the development of alternative financing models operating on the basis of online platforms.

The high potential of the development of these business financing models, their advantages in terms of speed, simplicity and affordability of attracting financial resources in comparison with traditional sources ensures their attractiveness both from the point of view of providers and recipients of financial resources. Therefore, the research of features, advantages and disadvantages of each model is an important component of their future development in general, as well as more active implementation in domestic practice.

\section{Literature review}

Coverage for alternative sources of funding in research to date is incomplete and fragmented. This is due, first of all, with relatively short history and dynamism of the development of this financing instrument. The most fundamental theoretical and analytical research on alternative financing today spend researchers at Cambridge Center Alternative Finance, including Bryan Zhang, Robert Wardrop, Tania Ziegler, Luke Deer, Andrew Grant and others. Among domestic researchers, individual models of alternative financing are considered in works by Krukhmal O.V., Medzhybovskaya N.S., Ogorodnik V.O., Petrushenka Yu.M., Dudkina O.V.. The purpose of the article is research of the theoretical aspects of the functioning of alternative finances, to organize the models of alternative financing.

\section{Methods and results}

In bank financial and credit institutions, attraction of funds on the stock market through issue and placement of securities broad terms the category of alternative financing include all channels to attract financial resources by individuals and entities other than, traditional lending bank and non- bank financial and credit institutions, attraction of funds on the stock market through issue and placement of securities. In this approach, alternative financing includes in particular funds raised by enterprises from domestic sources (for example, in the form of accounts payable, stable liabilities), as well as external alternative financing - loans from acquaintances and relatives, commercial and leasing loans. Today's most common approach is to consider essence of alternative financing as a means of attracting individuals and legal entities through the specialized online platforms platform.

Thus, the current understanding of alternative financing refers in using online platforms that create access to financial resources by passing the banking system or traditional non-bank financial intermediaries and provide direct linkages between borrowers and lenders (providers and recipients of financial resources). Innovative 
models of alternative financing are not only new sources and ways of raising funds, but also to use special equipment and online platforms, it is not only financial innovation, but above all the technical, the occurrence of which would not be possible without the current level of information systems.

The scope of alternative financing is developing very dynamically, existing models of alternative finance acquire new traits and on the basis of developing new models there is a well well-established common classification of alternative financing. Some researchers identify alternate funding models exclusively with crowdfunding platforms, considering peer-to-peer loans as one of the varieties of crowdfunding. This generalization, in our opinion, is inappropriate, because it does not take into account the key differences in peer-to-peer loans from crowdfunding, in particular with regard to the purpose of obtaining loans, the terms of payment of income for them and the types of entities to which they are provided.

It should be noted the presence of regional peculiarities in the development of each of the models of alternative financing, which complicates the possibility of their single typology and the establishment of characteristic features. Nevertheless, according to the classification proposed by the Cambridge Alternative Finance Center, which in our opinion is the most complete and comprehensive, the main types of alternative financing are peer-to-peer consumer loans (peer-to-peer consumer lending), peer-to-peer business loans ("peer-to-peer business lending"), balance sheet business loans, equity-based crowdfunding, non-financial overview ("rewardbased crowdfunding"), real estate crowdfunding, profit sharing on a profit basis ("profit sharing crowdfunding"), donation-based crowdfunding, invoice trading, debt-driven debt-based securities. The systematization of these basic alternative financing models, as well as other less popular varieties, is schematically presented in Figure 1.

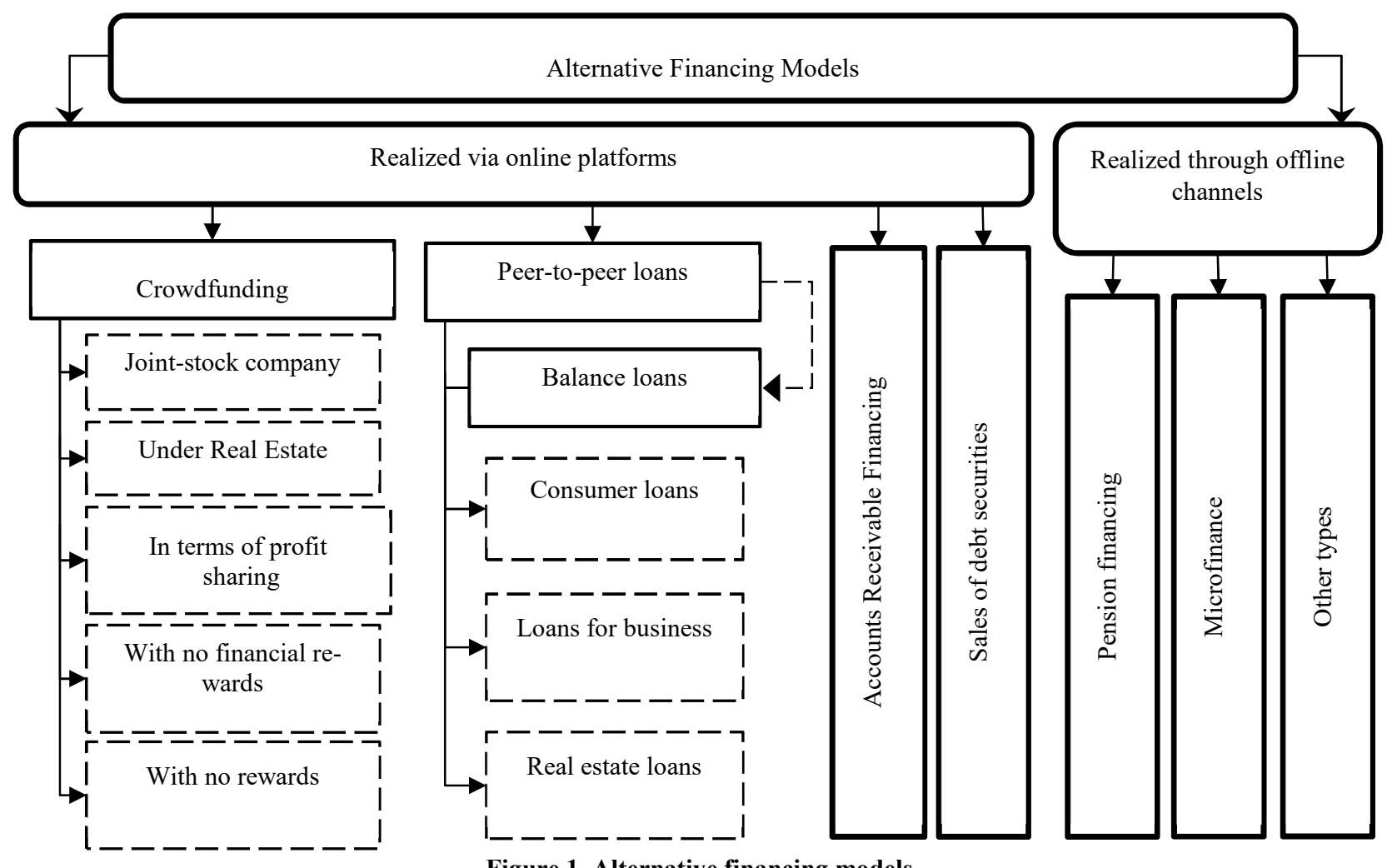

Figure 1. Alternative financing models

The main types of alternative financing models implemented through the online platform are crowdfunding and peer-to-peer loans. Peer-to-peer loans (peer-to-peer lending) are distributed mainly in the form of consumer lending, in which individuals receive a loan, usually for the satisfaction of their consumer goals directly from other individuals, as well as institutional investors (lenders) without the participation of a traditional financial intermediary (a bank, a credit union, etc.). Implementation of this mechanism is significantly simplified when using online platforms, which provide not only a "meeting" between the borrower and the creditor, but also scoring the borrower based on the tools for checking the creditworthiness of the platform,providing services for calculating, collection of overdue debts.

The formation of the required amount of peer-to-peer loans takes place by obtaining small amounts of unsecured personal loans from a number of other individual and institutional lenders. Using this model allows a 
borrower with a low credit rating obtain the necessary loan amount quickly and relatively inexpensively. For creditor, the advantage of this model is relatively higher income, comparing, for example, with bank deposits.

Because of the affordability, speed and cheapness of borrowing through peer-to-peer lending, this model has become attractive for small and medium-sized enterprises, which, due to lack of credit history or low credit ratings, can not obtain the required amount of borrowed resources at an affordable interest rate through traditional channels. Therefore, a separate type of peer-to-peer loans is peer-to-peer business loans (or peer-tobusiness loans). This model involves borrowing funds through an online platform for small and medium-sized enterprises in order to increase working capital, as well as to invest. It is in the aspect of peer-to-peer business loans attracted for investment purposes and innovative projects that this model can be considered as a kind of crowdfunding.

Typically intermediary that serves the online platform with peer-to-peer lending does not assume any credit risk, and provides mediation services only on commission. However, in some countries in the world, credit loans for businesses and individuals have gained popularity, in which the loan amount is directly deducted from the balance of the institution serving the online platform. Thus, the online platform of this model itself is a creditor with respect to borrowers - individuals, small and medium enterprises registered for the online service platform and made an application for a loan.

Summarizing the characteristics of peer-to-peer lending, Krukhmal O.V. outlines the following key features that distinguish this model from traditional channels of attraction of financial resources and other alternative financing models: online transactions; the absence of strains and previous relationships between the borrower and the creditor; an independent choice by the creditor of the loans in which he will invest; providing loans on the terms of return and payment; lack of collateral for loans and state insurance for repayment of the creditor.

Unlike peer-to-peer loans are mainly used by enterprises for increasing working capital, other alternative financing model - crowdfunding - aimed at financing start-ups, companies and ideas in the early stages of a project. In its essence crowdfunding is a voluntary association through an online platform of financial or other resources of many individual and institutional investors (providers of resources) to support efforts, ideas and projects of other people, organizations or individual communities.

The specific features of the crowdfunding that distinguish it from other alternative financing models, as well as from business angels and venture capitalists, are the following

The crowdfunding specific features that distinguish it from other alternative financing models, as well as business angels and venture capitalists are as follows:

- investments attracted through crowdfunding platforms are used to implement new projects and their financing in the early stages of implementation;

- crowdfunding allows simultaneously obtaining the necessary amount of comparatively "cheap" financial resources from investors and preserving control over business;

- crowdfunding can be applied to virtually any kind of activity - startups, social projects, media projects and anything else that may be of interest to investors;

- for the recipient of financial resources, the crowdfunding platforms are simpler and more understandable, often limited to placing on the Internet information about the project;

- the availability of the crowdfunding platforms through the Internet, which allows receiving funding regardless of the geographical location of the recipient.

Depending on the remuneration received by the investor from participation in the project, the following types of crowdfunding are distinguished: custodian with financial remuneration (joint stock-holding, profit-sharing on the terms of participation in profits), crowdfunding with non-financial remuneration and crowdfunding with no remuneration.

The most common model by the number of established platforms is currently crowdfunding with non-financial rewards. Such popularity of this type of crowdfunding is associated with the ability to use it effectively to raise funds on almost any projects and in the interests of any subject: through the non-financial reward crowd- 
funding individual entrepreneurs, small and medium businesses high-tech companies, multinational corporations, some individuals, artists and others raise funds. The main distinctive feature of this type of crowdfunding is the lack of a cash payment for the use of financial resources. Instead, money providers receive a nonfinancial reward, which can also take different forms - participation in product development, meeting with project creators, recollection in a movie, invitation to a concert, obtaining a sample of a manufactured product, etc. The widespread variant of the crowdfunding model of a non-financial revenge is participating in the presale order of the goods, that is, the investor has the right to receive the product after its production, obtaining the goods at the best price or with other benefits. Often it concerns new software, gadgets and technological innovations, and music albums, movies, books. It should also be noted that crowdfunding platform with nonfinancial rewards can be applied not only to attract seed money, but also to "study" of the market - determination of the potential demand for products to obtain confirmation of the social significance and importance of the project to attract customers, establishing partnership ties, grouping of communities and so on.

Crowdfunding with a lack of remuneration allows donors to support charitable, social and community projects that do not have financial or material returns. The recipients of financial resources do not, however, assume any obligations to donors (money providers).

The third kind of crowdfunding - crowdfunding with financial remuneration or crowdinvesting - covers several subsets, including joint stock collateral fangding, real estate collapse and profit sharing on profit participation.

Joint-Stock Custodian Funding is closest to venture capital investment, as it involves providing investor funds in exchange for company shares, dividends or voting rights at general shareholders' meetings. However, unlike venture investments, joint stock-holding crowdfunding provides financial resources from a large number of small investors, none of which obtains a pre-emptive right to manage an enterprise. Thus, entrepreneurs still have the opportunity to dispose of their business independently. At the same time, it should be noted that today more and more business angels and venture funds are involved in financing projects through the crowdfunding platforms.

Crowdfunding on real estate can be considered a type of share crowdfunding in which the recipient of funds is the developer company and the funds attracted through the placement of securities backed mortgage cover.

Crowdfunding in terms of participation in the profits (or model royalties) is an intermediate model between equity crowdfunding and crowdfunding with non-financial rewards. On the one hand, this model assumes that an investor receives a portion of income or profit from the project in the form of dividends, royalties or other payment, and on the other hand - allows the recipient of financial resources to retain control over the project (business).

In addition to the most popular alternative financing models, such as crowdfunding and peer-to-peer lending, it is also necessary to draw attention to such models of attracting financial resources online as debt financing and debt securities sales. These models, based on the nature of the transactions performed, are very similar to the existing services of traditional financial market intermediaries, but differ from them in that, like other alternative finance models, they are implemented through online platforms. Thus, receivables financing allows small and medium-sized enterprises to rapidly increase their working capital through sales through the online platform of their invoice with a certain discount to individual and institutional investors. This model is very similar to the traditional factoring service provided by bank and factoring companies.

Sales of debt securities as an alternative financing model, involves the sales of unsecured debt securities (usually long-term and maturing at the end of treatment) to individual and institutional investors online. The circulation of such securities in the stock market is limited due to unattractive investment characteristics. Typically, this tool is used in European countries by venture with renewable energy (for example, to finance wind power plants or solar-panel installation).

Pension financing ("pension-led funding") is also more appropriately classified as alternative financing models, although the use of this mechanism does not necessarily involve the attraction of funds online, but it involves the use of pension savings of business owners to finance certain investment projects, intangible assets. This model is most often used by owners of small and medium businesses, and retirement savings are used as collateral. 
In the proposed in Figure 1 classification of alternative financing models for the alternative finance category, which is implemented without the use of online platforms, microfinance is also included. The need to formulate this model for attracting financial resources was due to the need for local, targeted support for small and medium-sized businesses, as well as social projects of communities. Microfinance institutions, as a rule, are characterized by geographic restrictions on the distribution of their activities. Although today microfinance is actively exploiting the benefits of online platforms, but this is not an exclusive feature of this model: microfinance services can be provided both online and offline. The group of other types of alternative financing in Figure 1 includes all other possible sources of funds, other than the listed alternative models and traditional channels, including funds from relatives, commercial loans, etc.

The availability of a large number of alternative financing models requires them to be systematized according to key parameters, including: the type of financial resources provider, the type of recipient of financial resources, the purpose of attracting financial resources and the motivation to use alternative financing models, the basic principle of financing, the type of remuneration for the provider of financial resources. The classification of alternative financing models by these features is presented in Table 1.

Table 1. Characteristics of alternative financing models by key criteria

\begin{tabular}{|c|c|c|}
\hline Criterion & $\begin{array}{l}\text { Types / characteristics of the model by classifi- } \\
\text { cation criterion }\end{array}$ & Examples of alternative financing models \\
\hline \multirow{3}{*}{$\begin{array}{l}\text { Providers of financial } \\
\text { resources }\end{array}$} & Individuals (Individual Investors) & Peer-to-peer loans, Crowdfunding \\
\hline & $\begin{array}{l}\text { Institutional Investors (investment, pension, } \\
\text { venture funds, banks and others) }\end{array}$ & $\begin{array}{l}\text { Crowdfunding, as well as peer-to-peer loans } \\
\text { through trade organizers (online platforms) }\end{array}$ \\
\hline & $\begin{array}{l}\text { Trade Organizers (Online Alternate Funding } \\
\text { Platform) }\end{array}$ & Balance loans for business \\
\hline \multirow{2}{*}{$\begin{array}{l}\text { The main purpose of the } \\
\text { provider of financial re- } \\
\text { sources }\end{array}$} & Profit & $\begin{array}{l}\text { Peer-to-peer loans, joint stock collateral, profit } \\
\text { sharing on a profit basis }\end{array}$ \\
\hline & $\begin{array}{l}\text { Support for innovative ideas, implementation of } \\
\text { socially significant projects }\end{array}$ & $\begin{array}{l}\text { Crowdfunding with non-financial remuneration, } \\
\text { crowdfunding with no remuneration }\end{array}$ \\
\hline \multirow{4}{*}{$\begin{array}{l}\text { Recipients of financial } \\
\text { resources }\end{array}$} & Individuals & Peer-to-peer consumer loans \\
\hline & $\begin{array}{l}\text { Small and medium businesses, including indi- } \\
\text { viduals - entrepreneurs }\end{array}$ & $\begin{array}{l}\text { Peer-to-peer business loans, various types of } \\
\text { crowdfunding }\end{array}$ \\
\hline & Developers (construction companies) & Peer-to-peer real estate loans, real estate collapse \\
\hline & $\begin{array}{l}\text { Associations of citizens, non-profit organiza- } \\
\text { tions }\end{array}$ & $\begin{array}{l}\text { Crowdfunding with no remuneration, microfinance } \\
\text { (community securities) }\end{array}$ \\
\hline \multirow{3}{*}{$\begin{array}{l}\text { Formation of income } \\
\text { (remuneration) of the } \\
\text { provider of financial re- } \\
\text { sources }\end{array}$} & $\begin{array}{l}\text { Funding on the basis of share participation (in- } \\
\text { come - dividends, royalty) }\end{array}$ & Joint-stock crowdfunding, real estate crowdfunding \\
\hline & $\begin{array}{l}\text { Financing on the basis of debt participation (in- } \\
\text { come - interest) }\end{array}$ & $\begin{array}{l}\text { Ringer-to-peer loans, balance loans for business, } \\
\text { debt securities }\end{array}$ \\
\hline & $\begin{array}{l}\text { Lack of financial reward for the provider of fi- } \\
\text { nancial resources }\end{array}$ & $\begin{array}{l}\text { Crowdfunding with non-financial remuneration, } \\
\text { crowdfunding with no remuneration }\end{array}$ \\
\hline \multirow{4}{*}{$\begin{array}{l}\text { The purpose of attract- } \\
\text { ing financial resources }\end{array}$} & Satisfaction of consumer needs & Peer-to-peer consumer loans \\
\hline & $\begin{array}{l}\text { Realization of socially meaningful and other } \\
\text { unprofitable projects }\end{array}$ & $\begin{array}{l}\text { Crowdfunding with no remuneration, microfinance } \\
\text { (community securities) }\end{array}$ \\
\hline & Funding of working capital, increasing liquidity & Debt finance, peer-to-peer business loans \\
\hline & Financing of investment projects, start-ups & Crowdfunding \\
\hline \multirow[t]{2}{*}{$\begin{array}{l}\text { Motivation to use alter- } \\
\text { native financing }\end{array}$} & Maintaining maximum control over business & $\begin{array}{l}\text { Crowdfunding with non-financial remuneration, } \\
\text { crowdfunding with no remuneration }\end{array}$ \\
\hline & $\begin{array}{l}\text { Maximum speed and ease of attraction of finan- } \\
\text { cial resources }\end{array}$ & Peer-to-peer loans, joint stock crowdfunding \\
\hline
\end{tabular}

As noted, alternative financing models have gained different dynamics of development in different countries and regions of the world (Figure 2), which is related, in particular, to the national peculiarities of the functioning and accessibility of traditional channels for the financing of the needs of business and individuals, as well as certain restrictions, created at the legislative level (such as US business financing). 


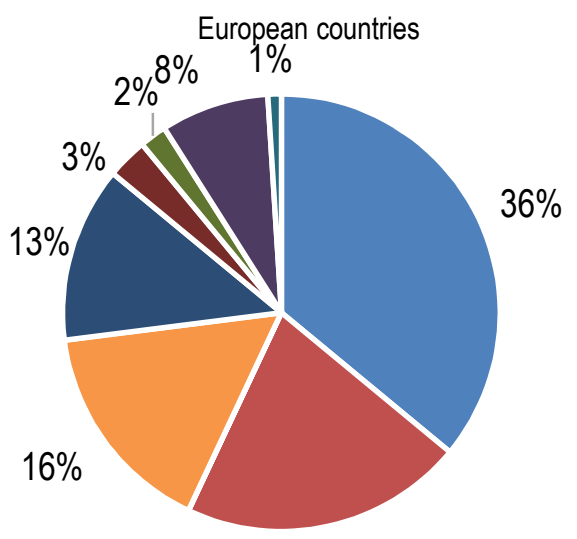

$21 \%$

Asia-Pacific Region (Except China)

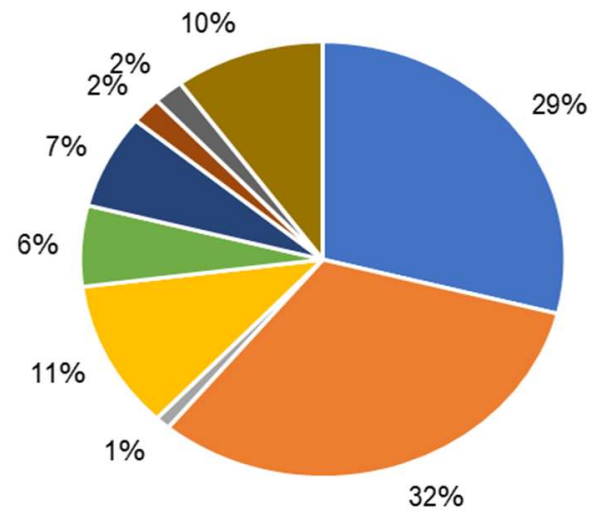

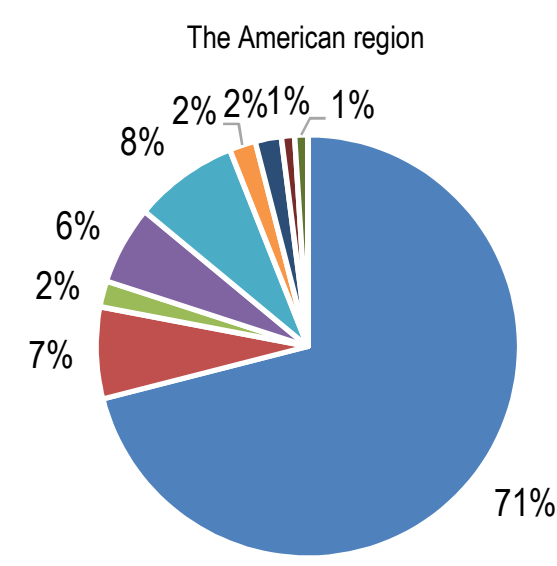

- Peer-to-peer consumer loans

- Peer-to-peer business loans

- Peer-to-peer real estate loans

= Balance loans for business

- Balance Loans for Individuals

- Joint-Stock Crowdfunding

- Craudfandings with non-financial rewards

- Craufandings for real estate

- Craudfandings with no rewards

- Accounts Receivable Financing

- Debt securities

Figure 2. Structure of distribution of alternative financing models in the regions of the world in $2015, \%$ (compiled by the author according to Wardrop, R., Zhang B.)

Analyzing the structure used alternative financing models in terms of the three major regions of the world (European countries, Asia-Pacific and the Americas) for 2015, includes the following features. In all regions of the world, peer-to-peer loans (57\%,73\% and 94\% respectively in the European, Asia-Pacific and Americas regions) account for the largest share of funds raised through alternative funding. It should be noted that the predominance of peer-to-peer loans for individuals in the Americas is $71 \%$ of the total amount of alternative financing in 2015. This is due to the fact that legal entities in the United States, in accordance with regulatory requirements, can receive loans only in the form of bank loans or through the issuance and placement of securities in the stock market. However, it should be noted that peer-to-peer loans are provided through registered online platform (specialized sites) in the United States by many researchers relate to a variety of crowdfunding.

This type of peer-to-peer loans, the balance of the loan, traditionally is quite popular in the Asia-Pacific region (11\%), and was widely spread in the countries of the American region ( $8 \%$ and $6 \%$ of the loans respectively for individuals and business). In European countries, this kind of alternative funding has not developed. Among the types of crowdfunding in all regions of the world the equity crowdfunding for non-financial rewards is the most popular. The use of alternative funding to replenish working capital through accounts receivable is used in European countries (8\%) and in Asia-Pacific countries (10\%).

\section{Conclusion}

Business financing alternative models based on the use of specialized online platforms provide a range of benefits (including speed, simplicity, accessibility) for attracting investments and working capital for small, medium businesses and large companies compared to traditional channels of additional financial resources through banks and the stock market. The growing popularity of alternative finance has resulted in the emergence of a large number of alternative financing models and their distribution in all regions of the world. 
However, further research requires the study of the specific use of alternative finance in certain regions and countries, identification of their strengths and weaknesses, and development of mechanisms to enhance the use of alternative models of business financing in less developed countries, including Ukraine.

\section{References}

1. Allen F. et al. (2012). Financial Intermediation, Markets, and Alternative Financial Sectors. Handbook of the Economics of Finance, 55 p. Access mode: http://apps.eui.eu/Personal/Carletti/Handbook_ACQV_25March2012.pdf.

2. Krukhmal O. V. et al. (2017). Peer-to-peer lending in Ukraine: perspectives of development and challenges for banks. International scientific journal Interscience, 2(2), 93-96. Retrieved from: http://nbuv.gov.ua/UJRN/mnj 2017 2\%282\%29 21

3. Medzhybovskaya N. S. (2016). Crowdfunding for small business: myth or reality? Economy of Ukraine, $10,20-35$.

4. Ogorodnik V. O. (2014). Crowdfunding as an innovative instrument for the modernization of the national financial and investment system, Scientific Bulletin of Uzhgorod University. Ser. : Economics, 3, 103105. Access mode: http://nbuv.gov.ua/UJRN/Nvuuec_2014_3_25.

5. Petrushenko Yu. M. et al. (2014). Crowdfunding as an innovative tool for financing projects of social and economic development. Marketing and Innovation Management, 1, 172-182.

6. Petrushenko Yu. M. (2014). Evolution of methods for collective funding as a factor of social and economic community development, World of Finance, 1, 106-113.

7. Segal M. et al. (2016). What is Alternative Finance? U.S. Small Business Administration; Economic Research Series. Access mode: https://www.sba.gov/sites/default/files/advocacy/What-Is-Alt-Fi.pdf.

8. Wardrop R. et al. (2016). Breaking New Ground: The Americas alternative finance benchmarking report, Cambridge Centre for Alternative Finance, 80 p. Access mode: https://www.jbs.cam.ac.uk/filead$\mathrm{min} /$ user_upload/research/centres/alternative-finance/downloads/2016-americas-alternative-financebenchmarking-report.pdf.

9. Zhang B. et al. (2016). Harnessing Potential: The Asia-Pacific alternative finance benchmarking report. Cambridge Centre for Alternative Finance, 96 p. Access mode: https://www.jbs.cam.ac.uk/filead$\mathrm{min} /$ user_upload/research/centres/alternative-finance/downloads/harnessing-potential.pdf. 